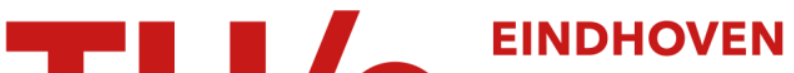

\section{Fractography of borosilicate glass tested in three- and four- point bending}

\section{Citation for published version (APA):}

Dielhof, M. H., Dortmans, L. J. M. G., \& With, de, G. (1993). Fractography of borosilicate glass tested in threeand four-point bending. Journal of the European Ceramic Society, 12(3), 215-220. https://doi.org/10.1016/09552219(93)90123-9

DOI:

10.1016/0955-2219(93)90123-9

Document status and date:

Published: 01/01/1993

\section{Document Version:}

Publisher's PDF, also known as Version of Record (includes final page, issue and volume numbers)

\section{Please check the document version of this publication:}

- A submitted manuscript is the version of the article upon submission and before peer-review. There can be important differences between the submitted version and the official published version of record. People interested in the research are advised to contact the author for the final version of the publication, or visit the $\mathrm{DOI}$ to the publisher's website.

- The final author version and the galley proof are versions of the publication after peer review.

- The final published version features the final layout of the paper including the volume, issue and page numbers.

Link to publication

\section{General rights}

Copyright and moral rights for the publications made accessible in the public portal are retained by the authors and/or other copyright owners and it is a condition of accessing publications that users recognise and abide by the legal requirements associated with these rights.

- Users may download and print one copy of any publication from the public portal for the purpose of private study or research.

- You may not further distribute the material or use it for any profit-making activity or commercial gain

- You may freely distribute the URL identifying the publication in the public portal.

If the publication is distributed under the terms of Article 25fa of the Dutch Copyright Act, indicated by the "Taverne" license above, please follow below link for the End User Agreement:

www.tue.nl/taverne

Take down policy

If you believe that this document breaches copyright please contact us at:

openaccess@tue.nl

providing details and we will investigate your claim. 


\title{
Fractography of Borosilicate Glass Tested in Three- and Four-Point Bending
}

\author{
M. H. Dielhof
}

Section of Computational and Experimental Mechanics, Faculty of Mechanical Engineering, PO Box 513 , 5600 MB Eindhoven, The Netherlands

\author{
L. J. M. G. Dortmans \& G. de With* \\ Centre for Technical Ceramics, PO Box 595, 5600 AN Eindhoven, The Netherlands
}

(Received 2 February 1993; accepted 31 March 1993)

\begin{abstract}
Most studies dealing with fractographic analysis are based on the occurrence of features, such as mirror. mist and hackle zones, formed symmetrically around a defect. Calculations are carried out hereupon. In this study, polished borosilicate specimens, and ground. annealed and chamfered borosilicate glass specimens are used for fractography. Six defect types could be distinguished, whereof four types deviate from simmetry. The strength data, obtained from threeand four-point bending, are described by a Weibull probability density function. Discontinuities present in the Weibull graphs were expected to be linked to the six defect populations. However, although glass is assumed to be an ideal and isotropic material, no such relationship has been found.
\end{abstract}

Die meisten Untersuchungen, die sich mit der Bruchbildanalyse befassen, basieren auf dem Erscheinungsbild des Bruches, wie z.B. Spalt-, faserige und Spitzbruchzonen, die sich symmetrisch um einen Defekt bilden. Dies dient als Ausgang für nachfolgende Berechnungen. In der vorliegenden Arbeit wurden polierte Borsilikatproben, geschliffene und angelassene Borsilikatglasproben sowie Borsilikatglasproben mit abgeschrägten Kanten mit Hilfe der Bruchbildanalyse untersucht. Die Festigkeitsdaten aus Drei- und Vierpunktbiegeversuchen werden duch eine Weibull-Wahrscheinlichkeitsdichtefunktion beschrieben. Diskontinuitäten in den Weibull-Kurven werden im Zusammenhang mit der Population von sechs Defektarten erwartet. Obgleich Glas als ideales und isotropes Material betrachtet werden kann. konnte jedoch keine solche Beziehung gefunden werden.

* Also affiliated with Philips Research Laboratories, P.O. Box 80000,5600 JA Eindhoven, The Netherlands.
La plupart des études utilisant l'analyse fractographique sont hasées sur la présence de caractéristiques telles que des zones miroirs, des zones accidentées ou diffuses formées simétriquement autour d'un défaut. Les calculs tiennent compte de ces faits. Dans ce travail, des échantillons de verres borosilicaté polis, ainsi que des échantillons usinés, recuits et chanfreinés ont été utilisés pour l'étude fractographique. Six types de défauts peuvent être distingués, parmi lesquels quatre types dévient de la simétrie. Les résultats de résistance, obtenus en flexion trois et quatre points, sont décrits par une fonction de densité de probabilité de Weibull. On s'attendait à ce que les discontinuités constatées dans les graphiques de Weibull soient liées aux six populations de défauts. Cependant, bien que le verre puisse être considéré comme un matériau idéal et isotrope, de telles relations n'ont pas été trouvées.

\section{Introduction}

Fractography of brittle materials is used to determine the origin of failure during strength testing. In general, this origin can be traced to material inhomogeneities, such as pores and microcracks, which occur either due to material processing (volume defects) or machining (surface defects). Fracture features, such as mirror, mist and hackle zones, and crack branching, are formed upon failure. Generally it is assumed that these are formed symmetrically around the critical defect. ${ }^{1-5} \mathrm{Calcul}-$ ations to obtain material parameters, such as mirror constant and fracture toughness, are carried out with the assumption that symmetric fracture features occur. ${ }^{4.6-9}$

In a number of cases, the bimodal behaviour of a Weibull graph was associated with different types of failure origin, such as the distinction between 
Table 1. Properties and dimensions of the borosilicate glass samples

\begin{tabular}{|c|c|c|c|}
\hline & Bars & Disk $^{1 a}$ & Disk $^{2 a}$ \\
\hline Dimensions (mm) & $\begin{array}{l}L=50 \\
H=4.5 \\
W=3.5\end{array}$ & $\begin{aligned} D & =20 \\
t & =1 \cdot 5\end{aligned}$ & $\begin{array}{c}D=30 \\
t=1 \cdot 5 \\
\end{array}$ \\
\hline Tolerance on dimensions ( $\mathrm{mm}$ ) & 0.1 & $0 \cdot 1$ & 0.1 \\
\hline Chamfer width $(\mathrm{mm})$ & 0.07 & - & - \\
\hline Roughness $(\mu \mathrm{m})$ & $<0 \cdot 1$ & $<0 \cdot 3$ & $<0 \cdot 3$ \\
\hline Flatness $(\mu \mathrm{m})$ & $<5$ & $<5$ & $<5$ \\
\hline Density $\left(\mathrm{g} / \mathrm{cm}^{3}\right)$ & $2 \cdot 21$ & $2 \cdot 51$ & 2.51 \\
\hline Poisson's ratio ${ }^{b}$ & 0.189 & 0.224 & $0 \cdot 224$ \\
\hline Young's modulus (GPa) ${ }^{h}$ & $61 \cdot 6$ & $71 \cdot 3$ & $71 \cdot 3$ \\
\hline
\end{tabular}

${ }^{a}$ Disk ${ }^{1}$ and disk ${ }^{2}$ represent the disks used for bor and ror respectively.

${ }^{n}$ Measured with the pulse-echo technique.

volume defects and surface defects, but without significant support of fractography. It is, however, clear that such a correlation can be made unequivocally. Therefore, some tests were done, in order to verify such a one-to-one correlation. Three- and four-point bend tests were done, and the resulting strength data are described by means of Weibull statistics. The chosen test material was glass, because of its assumed ideal behaviour and isotropy. Fracture features are examined by means of optical and scanning electron microscopy. For both the polished and the ground, annealed and chamfered series the relationship between the defect types and Weibull statistics has been studied.

\section{Experimental Procedure}

Two series of borosilicate glass specimens were prepared. The first series was ground and afterwards polished. The second series was ground and afterwards annealed, to reduce residual compressive stresses in the specimen surface. The annealing temperature was chosen at $540^{\circ} \mathrm{C}$ (within the annealing range of $525^{\circ} \mathrm{C}$ and $550^{\circ} \mathrm{C}$ ), to prevent deformation of the specimen due to weakening at the upper annealing temperature. Annealing at $540^{\circ} \mathrm{C}$, representative for a viscosity of $10^{14 \cdot 5} \mathrm{dPa}$, results in a stress reduction to about $0.6 \mathrm{MPa}$ after $1 \mathrm{~h}$ annealing. Strength testing was done in threepoint bending with span length $20 \mathrm{~mm}(3 \mathrm{pb} 20)$ and $40 \mathrm{~mm}$ (3pb40), and four-point bending ( $4 \mathrm{pb})$ with inner span length $20 \mathrm{~mm}$ and outer span length $40 \mathrm{~mm}$, ball-on-ring (bor) bending with loading radius $6 \mathrm{~mm}$, and ring-on-ring (ror) bending with inner loading radius $6 \mathrm{~mm}$ and outer loading radius $10 \mathrm{~mm}$. The crosshead speed of the testing machines was chosen corresponding to a strain rate of $5 \times 10^{-4} \mathrm{~s}^{-1}$. Dry conditions were achieved by means of flushing nitrogen gas with a dew point of $-35^{\circ} \mathrm{C}$ through a chamber enveloping the test jig. The fracture planes of the specimen tested in threeand four-point bending were examined by means of a Zeiss optical microscope with $30-40$ times magnification. SEM examination was done by means of a JEOL JSM-800A scanning electron microscope. The properties and the dimensions of the glass specimens are listed in Table 1 , where $L$ is the length of the bars, $H$ the height, $W$ the width, $D$ the diameter of the disks and $t$ their thickness.

\section{Results and Discussion}

Strength results for the ground and polished series are given in Table 2 . The strength distribution can be described by means of a Weibull probability distribution function. The Weibull distribution is calculated, according to ${ }^{10-12}$

$$
P_{\mathrm{f}}=1-\exp \left[-\left(\frac{\sigma_{\mathrm{f}}}{\sigma_{\mathrm{o}}}\right)^{m}\right]
$$

where $P_{\mathrm{f}}$ is the failure probability, $\sigma_{\mathrm{f}}$ is the failure strength, $\sigma_{\mathrm{o}}$ is the characteristic Weibull strength, and $m$ is the Weibull modulus. The Weibull modulus is calculated, using a least-squares fit with a weight function on the linearized Weibull equation. The failure probability $P_{i}$ is estimated by ${ }^{10-12}$

$$
P_{i}=\frac{i-0.5}{N}
$$

where $N$ is the total number of specimens and $i$ is the rank number. The weight function used was ${ }^{11.12}$

$$
w_{i}=\left[\left(1-P_{i}\right) \ln \left(1-P_{i}\right)\right]^{2}
$$

For the polished series, the Weibull graph is shown

Table 2. Results of the strength tests of the ground and polished borosilicate glass series

\begin{tabular}{lccrc}
\hline Batch & $N$ & Mean $\sigma_{\mathrm{f}}(M P a)$ & $m$ & $\sigma_{\mathrm{o}}(M P a)$ \\
\hline bor & 40 & $237 \cdot 3 \pm 51 \cdot 3$ & $5 \cdot 0$ & 242.6 \\
3pb20 & 40 & $200 \cdot 6 \pm 29 \cdot 9$ & $10 \cdot 9$ & 213.3 \\
3pb40 & 40 & $193 \cdot 4 \pm 21 \cdot 8$ & $10 \cdot 8$ & $202 \cdot 9$ \\
4pb40 & 40 & $160 \cdot 7 \pm 34.4$ & $5 \cdot 2$ & $177 \cdot 9$ \\
ror & 40 & $125 \cdot 7 \pm 31 \cdot 0$ & 3.4 & $134 \cdot 5$ \\
\hline
\end{tabular}




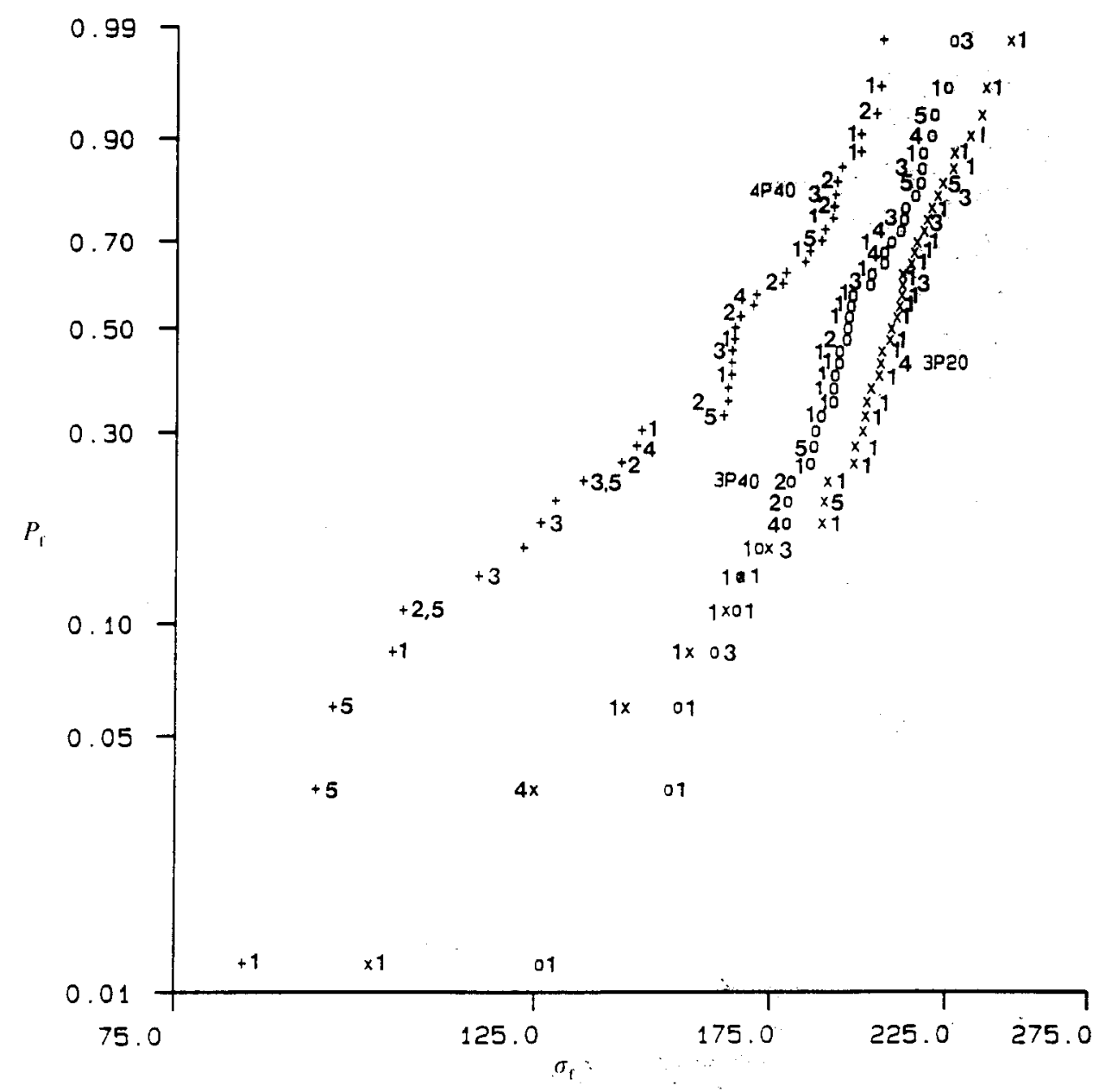

Fig. 1. Weibull graph: failure stress $\left(\sigma_{\mathrm{f}}\right)$ versus failure probability $\left(P_{f}\right)$ of the potished series, for three-point bending $(3 \mathrm{pb} 20$ and $3 \mathrm{pb} 40)$ and four-point bending $(4 \mathrm{pb})$. The numbers 1 to 5 represent the type 1 to type 5 defects. Type 6 defects do not occur.

in Fig. 1. The Weibull graphs show a decrease in strength from bor towards $3 \mathrm{pb} 20$, towards $4 \mathrm{pb} 40$, towards ror, corresponding to the increase in effective (tested) surface.

Fractography revealed four distinct regions on the fracture surface, surrounding the critical defect. ${ }^{1.4 .5 .13}$ These regions are, from the defect growing outwards, a mirfor zone (a flat and smooth region), a mist zone (small ridges parallel to the direction of crack propagation), a hackle zone (similar to the mist zone but larger ridges), and crack branching (the formation of two or more primary cracks), as is shown in Fig. 2.

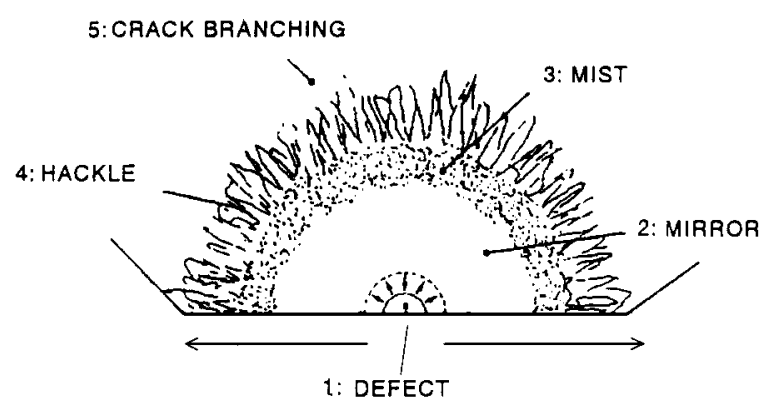

Fig. 2. Schematic diagram of fracture features, with mirror (2), mist (3) and hackle zones (4) and crack branching (5), surrounding the strength determining defect (1). The arrows represent the direction of maximum tensile stress.
In the literature, analysis of fracture surfaces has been carried out with the assumption that symmetric fracture features are formed around the strengthdetermining defect. ${ }^{1-5}$ The samples studied here show, however, that this is only true for $46 \%$ of the tested specimens of the polished series, and for $35 \%$ of the tested specimens of the annealed series. Six defect types could be distinguished. A description, assisted by SEM photographs, is given in Fig. 3.

The relationship between the defect types observed and the Weibull graphs is shown in Fig. 1 for the polished series. A decrease from high towards low strengths was expected to be followed by failure on type 1 defects at high strengths, from type 2 and 3 defects at intermediate strengths, and from type 5 and 6 defects at low strengths. Such a relationship, however, has not been found. The defects seem to be distributed randomly. This poor relationship was considered to be the result of residual compressive stresses on the specimen surface, caused by grinding and polishing.

Annealing is capable of removing the residual stress. However, it can possibly also affect the defect size distribution. Therefore, the effect of annealing upon Weibull statistics is studied. The Weibull modulus $m$ is 3.6 ( 20 specimens tested in $3 \mathrm{pb} 20$ ) for the annealed series, and 5.5 (20 specimens tested in 


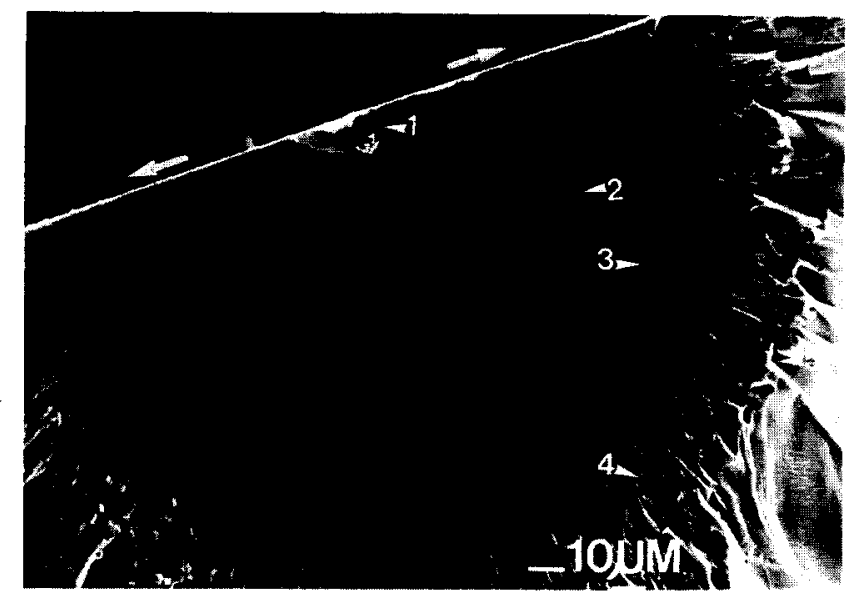

(a)

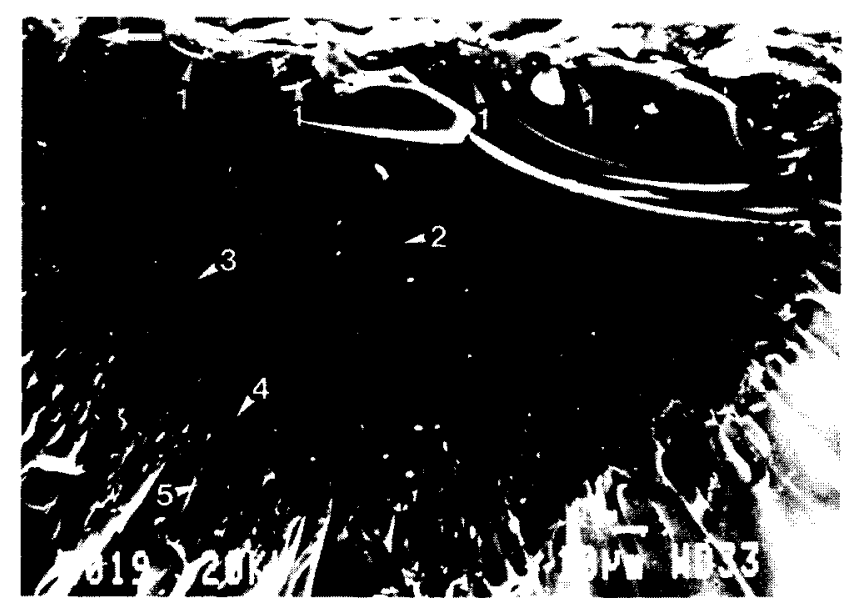

(c)

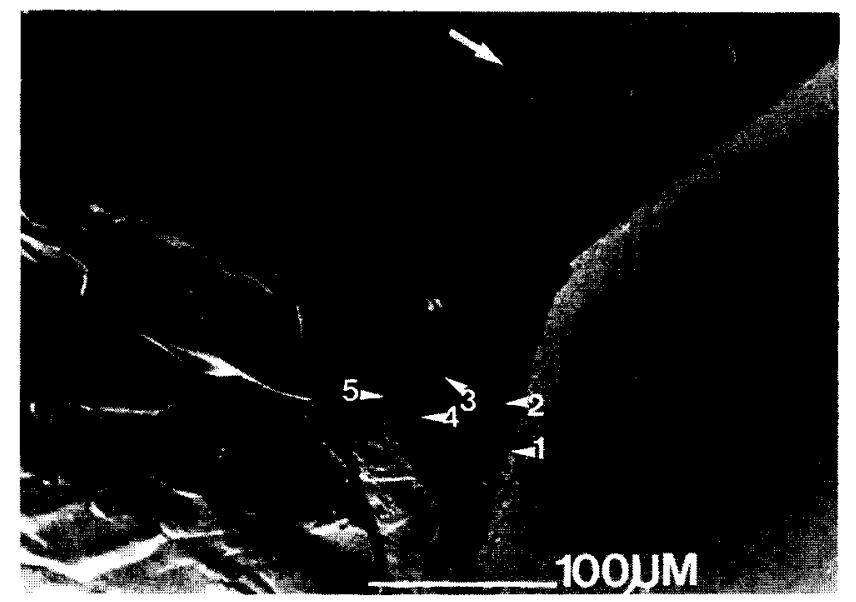

(e)

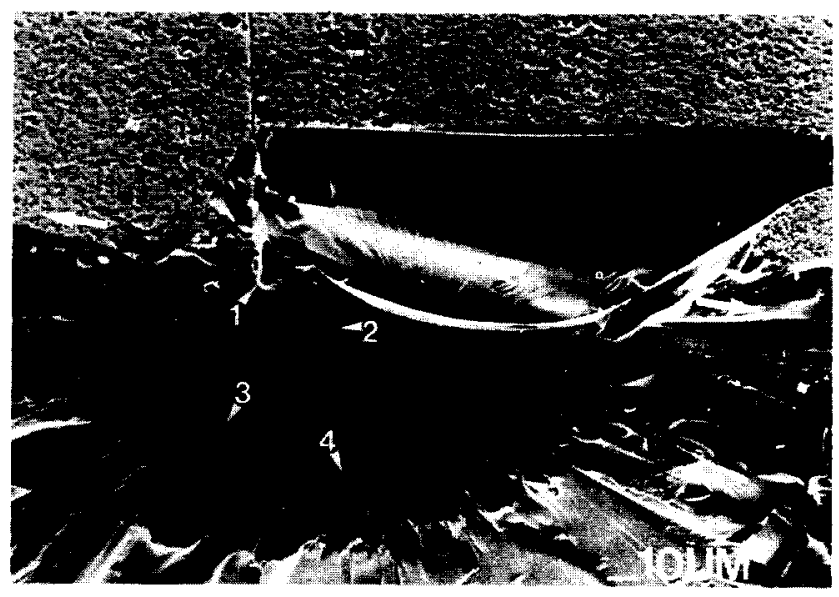

(b)

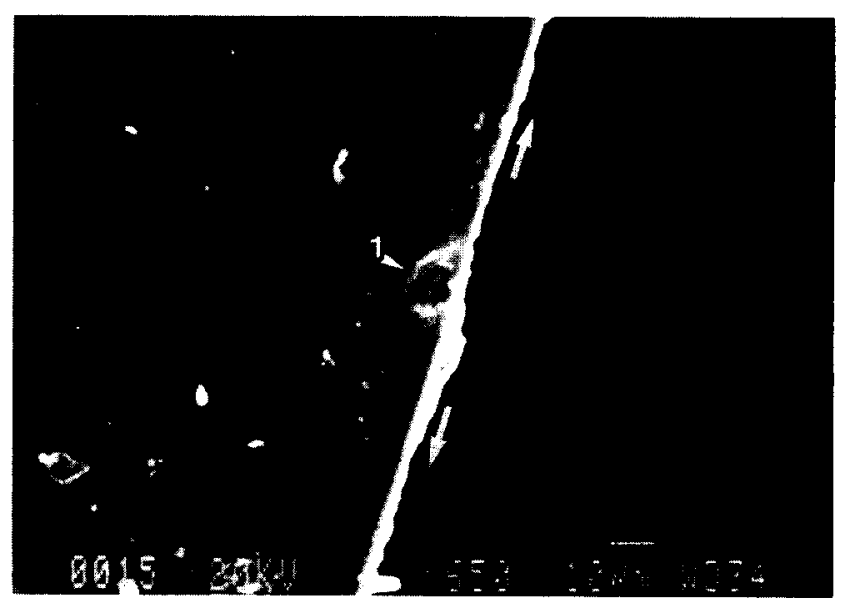

(d)

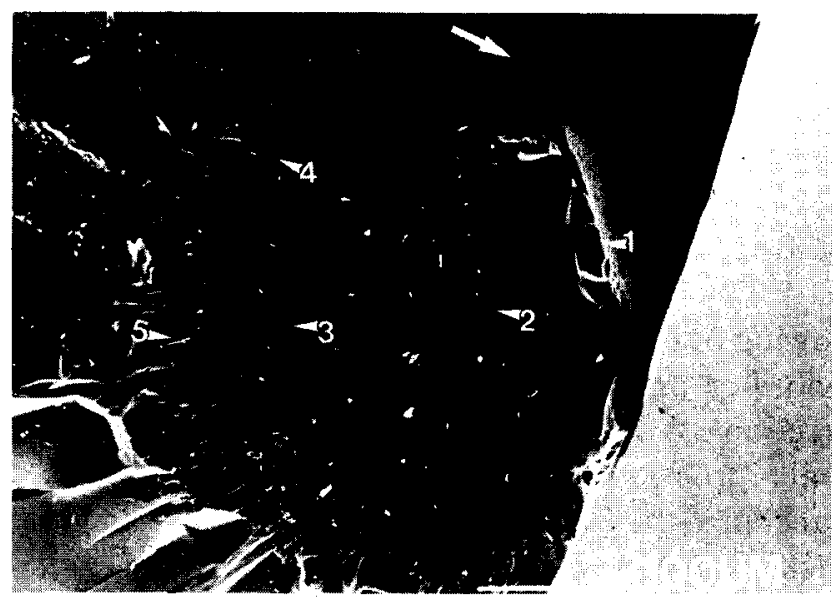

(f)

Fig. 3. Representative SEM photographs of the six defect types. The small white arrows show the defect (1), mirror (2), mist (3) and hackle zone (4) and crack branching (5). The large white arrows show the direction of maximum tensile stress. (a) The mirror is formed symmetrically around a surface defect (type 1), along the side of the bar of maximum tensile stress; (b) the mirror is formed strongly asymmetrically around a surface defect (type 2), along the side of the bar of maximum tensile stress; (c) the mirror is formed around several surface defects (type 3), which are located along the side of the bar of maximum tensile stress; (d) a volume defect (type 4), formed due to processing inhomogeneities; (e) a type 5 defect, which is located on the side of the bar; and (f) a type 6 defect, which is located at the chamfered edge.

$3 \mathrm{pb20)}$ for the non-annealed series. The $95 \%$ probability interval for $m$ for 20 samples is $4 \cdot 6 \pm 2 \cdot 5$. Annealing seems not to affect the defect populations significantly, as shown by the similar Weibull modulus for annealed and non-annealed ground specimens.
Results for the ground and annealed specimens showed strength data for $4 \mathrm{pb}$ samples below ror tested samples, which was not expected, according to the effective tested surface of both tests. Fractography on $4 \mathrm{pb}$ and $3 \mathrm{pb} 20$ tested samples indicated that $54 \%$ of all tested samples failed on about $10 \mu \mathrm{m}$ 
Table 3. Strength results of the annealed and chamfered borosilicate glass series

\begin{tabular}{lcccc}
\hline Batch & $N$ & Mean $\sigma_{\mathrm{f}}(\mathrm{MPa})$ & $m$ & $\sigma_{\mathrm{o}}(\mathrm{MPa})$ \\
\hline 3pb20 & 30 & $237.8 \pm 47.0$ & 6.2 & 259.8 \\
bor & 30 & $243.4 \pm 56.6$ & 4.5 & 262.7 \\
4pb40/20 & 30 & $180.4 \pm 49.8$ & 3.8 & 205.6 \\
ror & 30 & $125.7 \pm 31.0$ & 3.4 & 134.5 \\
\hline
\end{tabular}

defects at the edges of the test bars (type 6 defects). These edge defects were considered to be responsible for the lower strengths. Chamfering was done to remove the type 6 defects, which were introduced during grinding. A chamfer of $0.07 \mathrm{~mm}$ was considered to be sufficient.

Strength results for the ground, annealed and chamfered series are given in Table 3, accompanied by the Weibull graphs in Fig. 4. Fractography shows that the relationship between the defect types, which were comparable to those of the polished series, and Weibull statistics, is not understood, as for the polished series. Chamfering seems not to be sufficient to eliminate type 6 defects.

A slight tendency in the occurrence of defect types is noticed, however, from $3 \mathrm{pb} 20$ towards $4 \mathrm{pb}$. The occurrence of (ideal) type 1 defects decreases for the polished series from $68 \%$ for $3 \mathrm{pb} 20$, towards $53 \%$ for $3 \mathrm{pb} 40$, and $23 \%$ for $4 \mathrm{pb}$. For the annealed series a decrease of type 1 defects is found from $47 \%$ for $3 \mathrm{pb} 20$, towards $23 \%$ for $4 \mathrm{pb}$. This behaviour is followed by an increase in effective tested surface from three-point bending towards four-point bending. The larger the effective tested surface becomes, the more other than ideal (type 1) defects are present.

\section{Conclusions}

In spite of the ideal and isotropic behaviour of glass, in which the defects can be traced and classified very well, no relationship has been found for the polished series and the annealed and chamfered series between the observed defect types and Weibull statistics. Therefore, the identification of different failure origins from Weibull graphs alone without fractography is useless. Fractographic studies on less ideal and more crystalline materials will be more difficult. The poor relationship between Weibull statistics and the observed defect types of the polished series cannot be ascribed to compressive residual stresses on the specimen surface only, because the annealed series show a comparable poor relationship. Annealing is considered not to affect the defect populations caused by grinding. The type 6 defects along the edges of the test bars, which are assumed to reduce the failure strength, could only

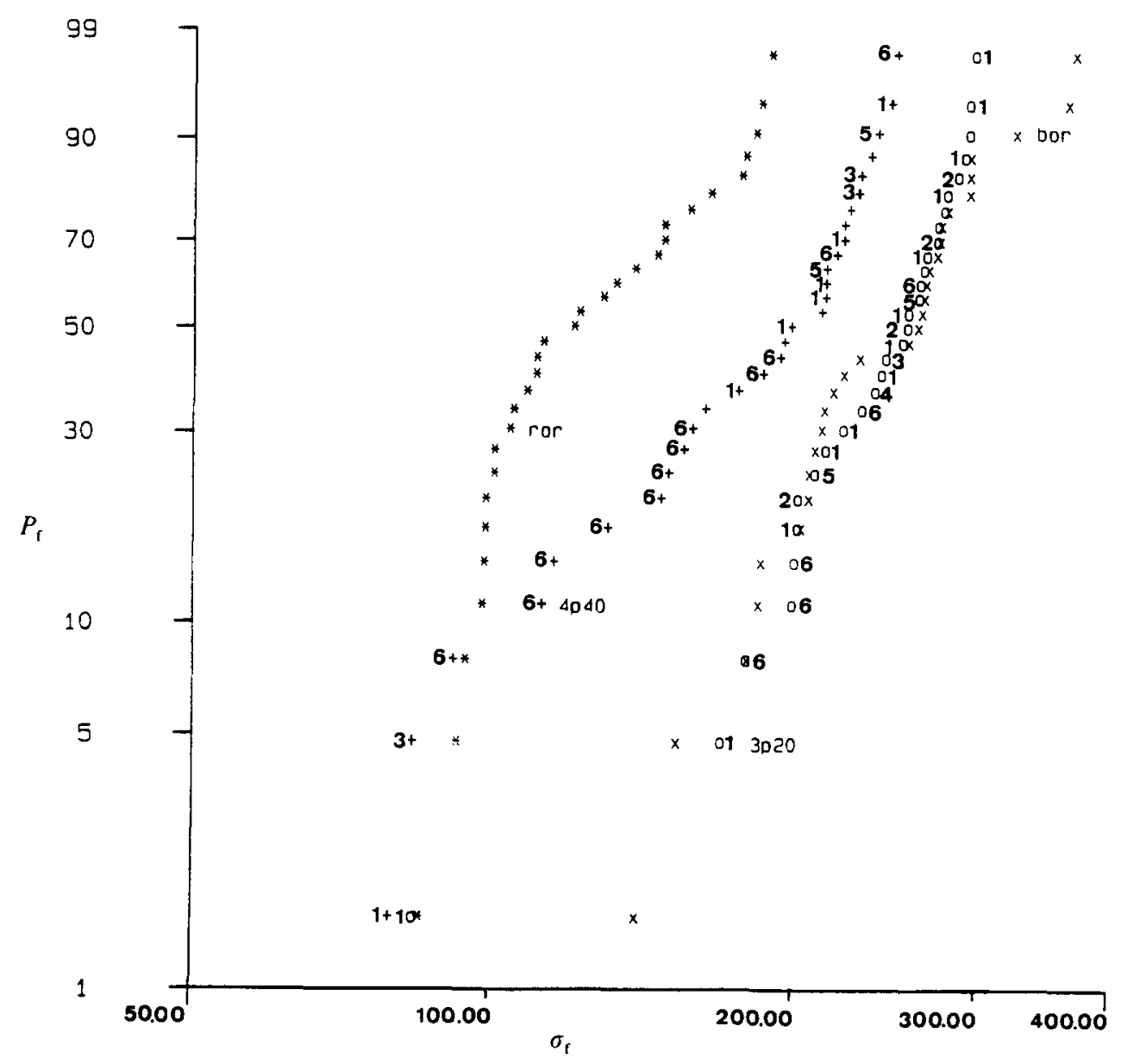

Fig. 4. Weibull graph for the annealed and chamfered series for bor, $3 \mathrm{pb} 20,4 \mathrm{pb} 40$ and ror bending. The numbers 1 to 6 represent the type 1 to type 6 defects. 
partly be removed by means of chamfering. They are absent in the polished series as a result of the polishing step.

\section{References}

1. Ball, M. J., Landini, D. J. \& Bradt, R. C., In Fractography of Ceramic and Metal Failures, ASTM STP 827, 1984, pp. $110-19$.

2. Freiman, S. W., Brittle fracture behavior of ceramics. Ceram. Bull., 67 (1988) 392-402.

3. Von Kerkhof, F., Bruchentstehung und Bruchausbreitung im Glas. Glastechnische Fabrikationsfehler, 423-584.

4. Mecholsky, J. J. Jr \& Freiman, S. W., Determinations of fracture mechanics parameters through fractographic analysis of ceramics. In Fractography of Ceramic and Metal Failures, ASTM STP 827, 1984, pp. 136-49.

5. Rice, R. W., Ceramic fracture features, observations, mechanisms and uses. In Fractography of Ceramic and Metal Failures, ASTM STP 827, 1984, pp. 5-119.

6. Fett, T., Stress intensity factors for semi-elliptical surface cracks in a plate under tension based on Isida's solution. Int. J. Fract., 48 (1991) 139-51.

7. Kirchner, H. P., Gruver, R. M. \& Scotter, W. A., Use of fracture mirrors to interpret fracture in brittle materials. $J$. Amer. Ceram. Soc., 58 (1975) 188-91.

8. Mecholsky, J. J. Jr, Freiman, S. W. \& Rice, R. W., Effect of grinding on flaw geometry and fracture of glass. J. Amer. Ceram. Soc., 60 (1977) 114-17.

9. Mecholsky, J. J. Jr, Rice, R. W. \& Freiman, S. W., Prediction of fracture energy and flaw size in glasses from measurement of mirror size. J. Amer. Ceram. Soc., 57 (1974) 440-3.

10. Balaba, W. M. et al., Probability estimators for Weibull statistics of the failure strengths of brittle powder compacts. J. Mat. Sci. Lett., 9 (1990) 648-9.

11. Bergman, B., How to estimate Weibull parameters. In Brit. Ceram. Proc., Engineering with Ceramics 2, Vol. 34, 1987, pp. 175-85.

12. Faucher, B. \& Tyson, W. R., On the determination of Weibull parameters. J. Mat. Sci. Lett., 7 (1988) 1199-203.

13. Richerson, D. W., Modern Ceramic Engineering, Marcel Dekker, New York, 1982, pp. 325-73.

\section{Bibliography}

Bansal, G. J., Effect of flaw shape on strength of ceramics. $J$. Amer. Ceram. Soc., 59 (1976) 87-8.

Charif, A. \& Osterstock, F., On the fracture statistics of polycrystalline $x-\mathrm{SiC}$ at room and high temperature. Mat. Sci. Eng., B11 (1992) 299-302.

Hlavac, J., The Technology of Glass and Ceramics, an Introduction. Elsevier, Amsterdam, 1983, pp. 163-9.

Mechalske, T. A., Fractography of slow fracture in glass. In Fractography of Ceramic and Metal Failures, ASTM STP 827, 1984, pp. 121-35.

Van Mier, J. G. M. (ed.), Fracture Processes in Concrete, Rock and Ceramics, E\& FN SPON. Chapman \& Hall, London, 1991, pp. 83-92.

Morey, G. W., Properties of Glass, American Chemical Society Monograph Series, No. 124. Reinhold Publishing Corporation, New York, 1954, pp. 166-90.

Noguchi, K. et al., Strength analysis of yttria-stabilized tetragonal zirconia crystals. J. Amer. Ceram. Soc., 73 (1990) $2667-76$.

Quinn, Q. D. \& Morrell, R., Design data for engineering ceramics: a review of the flexure test. J. Am. Ceram. Soc., 74 (1991) 2037-66. 